\title{
Interactions between Human Neutrophils and Vaccinia Virus: Induction of Oxidative Metabolism and Virus Inactivation
}

\author{
JAMES F. JONES ${ }^{(37)}$ \\ Department of Pediatrics, University of Arizona College of Medicine, Tucson, Arizona, USA
}

\begin{abstract}
Summary
The possible role of human neutrophils (PMN) as direct effector cells against free live virus particles was tested in vitro. Oxygen consumption, production of chemiluminescence and "virus killing" by PMNs was examined during and after incubation of cells and live or dead vaccinia virus with and without specific antibody. Oxygen consumption and chemiluminescence production occurred with unopsonized live but not with inactivated virus and was greatly enhanced with opsonization. Virus titers were determined in PMNfree supernatant and freeze-thawed cell pellet fractions after 15 min incubation. Reduction in titer from virus control was seen in supernatant fractions with and without opsonins, but in the cell fraction only with opsonins; the degree of reduction with opsonins was directly related to the opsonin source. PMNs from a patient with chronic granulomatous disease did not inhibit virus replication. These data suggest an active role for human PMNs in the genesis of and defense against virus infections and indicate areas for further investigation.
\end{abstract}

\section{Speculation}

Human neutrophils may play a role in the pathogenesis of and control of virus infections.

Human polymorphonuclear leukocytes (PMNs) are highly effective, mobile phagocytic cells. Their primary purpose, engulfing and destroying microorganisms, is facilitated by a variety of intrinsic mechanisms (14). Their role in defense against bacteria and fungi in the intact host and the consequences of their deficiency in number or function is well recognized $(3,22)$. The role of PMNs in defense against virus infections has not been examined in depth. Until recently most investigations have centered on the deleterious effect of viruses on PMN function (9, 16, 25, 33).

Possible effector roles for PMNs in virus infections have been described in virus-infected tissue culture systems. Bovine and human PMNs kill virus infected cells via antibody-dependent cellmediated cytotoxicity $(32,21)$. In addition, when bovine PMNs are cultured with virus antigen, an interferon-like substance substance is produced (23).

Direct killing of virus by PMNs by products of oxidative metabolism has been suggested by Belding et al. (4). These investigators showed that polio and vaccinia virus could be killed in an acellular system containing myeloperoxidase, $\mathrm{H}_{2} \mathrm{O}_{2}$ and halide ions. These data supported the observation of McFarlane et al. (18) who showed depressed killing of vaccinia and herpes simplex viruses by PMNs from a child with chronic granulomatous disease (CGD).

Further evidence for direct stimulation of PMN oxidative metabolism by killed mumps virus and influenza virus was recently provided by Brogan and Sagone (5) and Sosman and Busse (28), respectively.

The study reported here examined the direct interaction be- tween human PMNs and live vaccinia virus. The purposes of this investigation were to determine if oxidative metabolism of PMNs is stimulated, if specific opsonins are required and if virus is inactivated during short-term incubation with PMNs.

\section{MATERIALS AND METHODS}

PMNs. Human PMNs were obtained from previously vaccinated healthy adult volunteers and a patient with CGD after informed consent was obtained. Venous blood was collected in preservative-free heparin (Abbott Laboratories, North Chicago, IL) $(1 \mathrm{U} / \mathrm{ml})$ and sedimented with hydroxyethyl starch (McGaw Laboratories, Irvine, CA) (10). After washing twice in Hank's balanced salt solution buffy coat cells were applied to a Ficoll (Pharmacia, Inc., Piscataway, NJ)-Hypaque (Winthrop Laboratories, New York, NY) density gradient and PMNs collected and washed after hypotonic lysis of red blood cells. PMNs were suspended in Minimal Essential Medium (MEM) (GIBCO) at 1 $\times 10^{7} / \mathrm{ml}$. Cells obtained by this procedure were $98 \%$ PMNs and 95-98\% viable as determined by trypan blue exclusion.

Virus. Vaccinia virus (Dryvac/Wyeth Laboratories, Marietta, PA) was grown and passd multiple times in LLC-MK2 cells. Fresh LLC-MK 2 were grown 5 days and inoculated with approximately 4 plaque-forming units (PFU) per cell in MEM with $2 \%$ fetal calf serum and antibiotics. The supernatant was harvested after $48 \mathrm{~h}$ of incubation at $37^{\circ} \mathrm{C}$ in $5 \% \mathrm{CO}_{2}$, freeze-thawed five times and centrifuged $30 \mathrm{~min}$ at $1000 \mathrm{rpm}$. Tissue culture control was prepared in the same manner. The technique of Joklik (13) was used to purify the virus. Forty volumes of supernatant were layered over $5 \mathrm{ml}$ of $36 \%$ sucrose and centrifuged at $23000 \times \mathrm{g}$ for $2 \mathrm{~h}$ in a Beckman (Cedar Grove, NJ) L5-65B ultracentrifuge. Pellets were suspended in $0.008 \mathrm{M}$ Tris, pH9, layered over $36 \%$ sucrose, and centrifuged again at $23000 \times g$ for $2 \mathrm{~h}$. Pellets were suspended in MEM-FCS and titrated for virus. LLC-MK2 cells were grown in $35 \mathrm{~mm}$ Petri dishes (Falcon, Cockeysville, MD) for 5 days. Ten-fold dilutions of stock or test samples were made and $0.1 \mathrm{ml}$ of each dilution added to the cell sheet. Adsorption took place for $1 \mathrm{~h}$ at $37^{\circ} \mathrm{C}$ in $5 \% \mathrm{CO}_{2}$ and was followed by the addition of MEM with $2 \%$ FCS. After $48 \mathrm{~h}$ of incubation, media was removed and cells fixed with formalin-crystal violet. Each dilution was assayed in triplicate. Inactivated virus was prepared by holding $4 \times 10^{7} \mathrm{PFU} / \mathrm{ml}$ virus at $60^{\circ} \mathrm{C}$ for $60 \mathrm{~min}$.

Opsonizing source. Although current connotation of the word opsonization refers to preparation for phagocytosis, the term was used here for all experiments in which virus was mixed with antivaccinia antibody and PMNs regardless of the endpoint of the experiment. One source of opsonin was heat inactivated $\left(56^{\circ} \mathrm{C}, 30\right.$ min) autologous serum obtained from the PMN donors. The sera were heat inactivated to remove the possible confounding variable of complement activation. Antivaccinia antibody titers in these sera ranged from 1:100-1:1000. Human Vaccinia Immune Globulin (VIG) (Hyland Laboratories, Costa Mesa, CA) at $16.5 \%$ solution of gamma globulin portion of human serum obtained 
from recently vaccinated adults, was utilized unaltered, or after filtration (FVIG) through a $0.2 \mu \mathrm{m}$ filter (Millipore Corporation, Bedford, MA) to remove aggregated globulins. VIG used in this study was prepared in 1974 by Hyland and kindly provided by the CDC, Atlanta, Georgia; these studies were performed from 1976-1980. The antivaccinia antibody titer in the VIG preparations was 1:8000, as performed by the standard method of Downie and Kempe (8).

Oxygen consumption. $\mathrm{O}_{2}$ consumption was measured polaragraphically with a Clark electrode (30). Six $\times 10^{6} \mathrm{PMN}, 4 \times 10^{5}$ PFU virus and $0.1 \mathrm{ml}$ opsonin brought to a total volume of $1 \mathrm{ml}$ in Krebs Ringer Lactate buffer, $\mathrm{pH} 7.4$, were incubated in a water jacketed chamber at $37^{\circ} \mathrm{C}$ with constant mixing for $15 \mathrm{~min}$. Oxygen consumption is reported in nmoles $\mathrm{O}_{2} / \mathrm{h} / 10^{8}$ cells.

Virus inactivation. Purified virus $\left(4 \times 10^{5} \mathrm{PFU}\right.$ in MEM) were incubated under varying conditions for $15 \mathrm{~min}$ at $37^{\circ} \mathrm{C}$ in $12 \times 75$ $\mathrm{mm}$ plastic tubes with constant rotation $(7 \mathrm{rpm} / \mathrm{min})$. The tubes were then centrifuged in the cold for $3 \mathrm{~min}$ at $200 \times g$ to separate PMNs from the virus which remained in the supernatant. The PMNs were disrupted by three freeze-thaw cycles and volume brought up to $0.2 \mathrm{ml}$. Five-hundredths $\mathrm{ml}$ were diluted to $1: 100$, 1:500 and 1:1000 in Hank's balanced salt solution. Two-tenths ml quantities of supernatant and cell pellet contents were then cultured for virus as described above. The quantity of virus in each fraction was analyzed and recorded as the mean of duplicates for each dilution. Since no differences were seen at the varying dilutions, the final results are represented as the quantity of virus in the supernatant or pellet fractions. Vials without cells were treated as if cells were present.

Chemiluminescence. Reaction vessels ( $15 \mathrm{~mm}$ cylindrical) were stored in the dark for 20-24 h before use. One $\mathrm{ml}\left(1 \times 10^{6}\right)$ PMNs, $3 \times 10^{6}$ PFU of purified vaccinia $(0.1 \mathrm{ml})$, and $1 \mathrm{ml}$ luminol enriched FCS $11 \mathrm{mg}$ luminol (Sigma Chemical Co., St. Louis, $\mathrm{MO}) / 5 \mathrm{cc}$ FCS] (1) were incubated with test opsonin in a final volume of $5 \mathrm{ml}$ of MEM. Using a Beckman (Cedar Grove, NJ) LS-230-scintillation counter in the coincidence mode and the tritium window, each vessel under each experimental condition was counted $1 \mathrm{~min}$ under the cycle-repeat condition for $3 \mathrm{~h}$. Components of each experiment were added immediately before insertion of the vessel into the counter. All experiments were performed at ambient temperature without further mixing in the vessel.

\section{RESULTS}

$\mathrm{O}_{2}$ Consumption. Initial $\mathrm{O}_{2}$ consumption studies performed using unpurified virus preparations at titers of $4 \times 10^{6} \mathrm{PFU} / \mathrm{ml}$ showed that a ratio of $1: 2.5$ virus PFU:PMN was required to demonstrate $\mathrm{O}_{2}$ consumption with unopsonized virus. Identically prepared noninfected tissue culture controls did not produce $\mathrm{O}_{2}$ consumption. Increasing the PMNs above $6 \times 10^{6}$ increased the background activity, thus precluding detection of changes in $\mathrm{O}_{2}$ utilization.

Table 1 summarizes the results of the experiments undertaken with the above restrictions. A small but reproducible amount of $\mathrm{O}_{2}$ was consumed when unopsonized virus was incubated with PMNs. If a high titered antivaccinia antibody preparation (VIG) was used with PMNs and virus, 8,000 nmoles $\mathrm{O}_{2} / \mathrm{h} / 10^{8}$ cells was consumed. When VIG alone was added to PMNs a similar degree of $\mathrm{O}_{2}$ consumption was observed. This capacity to stimulate $\mathrm{O}_{2}$ consumption was removed when FVIG was used. The aggregation of gammaglobulin, which is known to stimulate $\mathrm{O}_{2}$ consumption, may have been responsible (11). Addition of FVIG to PMNs and virus resulted in a significant increase in $\mathrm{O}_{2}$ consumption. The amount of $\mathrm{O}_{2}$ consumption was directly dependent on VIG or FVIG concentration. The significant differences, however, between $\mathrm{O}_{2}$ consumption by PMNs with VIG alone and PMN, FVIG, virus suggest that aggregated IgG was a more potent stimulus than antibody-virus complexes, at least at the virus concentration utilized.

Chemiluminescence (CL). The restrictions under which the $\mathrm{O}_{2}$ consumption studies were performed led to two changes in the experimental methods. First, the virus preparation was concentrated by purification and, second, a more sensitive and versatile system of measurement of oxidative metabolism (CL) was established. Table 2 summarizes the peak CL values (attained at $60-90$ min of incubation) recorded when a total of $1 \times 10^{6}$ PMNs were used in each experiment.

Resting levels of CL by PMN were negligible throughout the incubation period. The moderate CL induced by addition of VIG was virtually eliminated when this material was filtered. Contrary to the $\mathrm{O}_{2}$ consumption experiments, incubation of PMNs and virus alone produced considerable amounts of $\mathrm{CL}$. This difference may be due to the increased ratio of virus to PMN, 3:1, used in these experiments or to the increased sensitivity of the CL assay. Heat-inactivated autologous (to PMN) serum from vaccinated donors also enhanced CL production when mixed with virus, but to a lesser extent than FVIG. The levels of $\mathrm{CL}$ produced with FVIG, virus and PMN are of the same order of magnitude as with opsonized killed staphylococci and PMNs; i.e., peak CL of 800,000 CPM attained in $30 \mathrm{~min}$.

The versatility of the CL assay allowed for testing the effect of altering the amount of virus in the assay (Table 3). An increase in unopsonized virus while PMN number remained the same had a positive effect on peak CL production. Heat-killed virus, however, did not induce $C L$ at similar concentrations.

Table 1. Oxygen consumption by neutrophils (PMNs) alone or with opsonins and live viruses

\begin{tabular}{llll}
\hline Experimental conditions & \multicolumn{1}{c}{$\begin{array}{c}\text { nmoles } \\
\mathrm{O}_{2} / \mathrm{h} / 10^{8} \text { cells }\end{array}$} & \multicolumn{1}{c}{$P$ value } \\
\hline PMNs and buffer & $2,308 \pm 215^{2}$ & & \\
PMNs, buffer, virus & $2,626 \pm 381$ & $<0.05^{3}<0.0001^{4}$ \\
PMNs and VIG & $6,796 \pm 2,431$ & $<0.001<0.05$ \\
PMNs and FVIG & $2,707 \pm 601$ & $<0.05<0.0001$ \\
PMNs, FVIG, virus & $4,729 \pm 807$ & $<0.0001$ \\
\hline
\end{tabular}

${ }^{1}$ Oxygen consumption was recorded by a Clarke electrode during a 15 min incubation under constant mixing at $37^{\circ} \mathrm{C}$ of $6 \times 10^{6} \mathrm{PMNs}, 4 \times 10^{5}$ PFU live vaccinia virus with or without $0.1 \mathrm{ml}$ opsonin in a total volume of $1.0 \mathrm{ml} \mathrm{Krebs-Ringer} \mathrm{phosphate} \mathrm{buffer,} \mathrm{pH} 7.4$.

${ }^{2}$ Values are reported as mean \pm S.D. of 10 experiments.

${ }^{3}$ Compared to PMNs and buffer (paired $t$ test).

${ }^{4}$ Compared to PMNs, FVIG and virus (paired $t$ test).

${ }^{5}$ Vaccinia immune globulin.

${ }^{6}$ Filtered $(0.2 \mu)$ vaccinia immune globulin.

Table 2. Chemiluminescence production by neutrophils (PMNs), alone or with opsonins and live virus ${ }^{1}$

\begin{tabular}{lcc}
\hline \multicolumn{1}{c}{ Experimental conditions } & $\begin{array}{c}\text { Count per min } \\
\text { per tube }\end{array}$ & $P$ value $^{2}$ \\
\hline PMNs, buffer $^{3}$ & $1,422 \pm 437(5)^{2}$ & \\
PMNs, VIG $^{4}$ & $10,000 \pm 3,400(2)$ & $<0.05^{4}$ \\
PMNs, FVIG $^{5}$ & $4,800 \pm 3,300(3)$ & \\
PMNs, serum (HI) $^{6}$ & $4,200 \pm 2,800(3)$ & $<0.01$ \\
PMNs, virus & $233,000 \pm 119,000(5)$ & \\
PMNs, virus, serum (HI) & $558,500 \pm 200,000(10)$ & $<0.01$ \\
PMNs, virus, FVIG & $738,000 \pm 60,000(11)$ & \\
\hline
\end{tabular}

${ }^{1}$ Peak chemiluminescence produced during the incubation of varying mixtures of $1 \times 10^{6} \mathrm{PMNs}, 3 \times 10^{6} \mathrm{PFU}$ purified vaccinia virus, $0.1 \mathrm{ml}$ opsonin, and $1 \mathrm{ml}$ luminol enriched fetal calf serum (1 mg luminol $/ 5 \mathrm{ml}$ FCS) in $5 \mathrm{ml}$ total volume of MEM was recorded in the in-coincidence mode of a Beckman LS-230 scintillation counter at ambient temperature without mixing.

${ }^{2} P$ value of an unpaired $t$ test.

${ }^{3}$ Values are given as mean \pm S.D. (number of experiments).

${ }^{4}$ Vaccinia immune globulin.

${ }^{5}$ Filtered $(0.2 \mu)$ vaccinia immune globulin.

${ }^{6}$ Heat inactivated $\left(56^{\circ} \mathrm{C}, 30 \mathrm{~min}\right)$. 
Opsonization with heat-inactivated autologous serum increased both the peak and rate of CL production. The time required to reach peak CLK production was affected to a lesser degree. This latter parameter may be dependent on experimental conditions as the CL studies were performed at ambient temperatures without mixing (Table 4).

Virus "killing." Both the induction of $\mathrm{O}_{2}$ consumption and the production of CL observed here suggested that virus-PMN interactions produce conditions compatible with virus inactivation. Virus to PMN ratios were $1: 2.5$ as in the $\mathrm{O}_{2}$ consumption experiments. The quantity of virus present at the initiation of the experiment was compared to residual amount after $15 \mathrm{~min}$ of incubation under varying conditions.

Fifteen min was chosen as the experimental period as $\mathrm{O}_{2}$ consumption peaked at this time and $\mathrm{CL}$ production was likewise at its greatest rate. This period is usually not adequate for complete bacterial killing, nor is it optimum for virus neutralization by antibody and/or complement $(17,27)$; but it may be of advantage in controlling for these latter effects and allow initiation of viral killing. Table 5 documents the results of these experiments and compares the amount of viable virus in the supernatant fraction to that remaining in the cell pellet fraction.

When no opsonins were added, the amount of virus present in the supernatant was less than virus incubated alone. However, virus associated with the cell pellet ranged from $0.62 \times 10^{5}-1.5$ $\times 10^{5} \mathrm{PFU} / 0.2 \mathrm{ml}$. This was the only situation where virus concentration in the pellet fraction appeared to increase during the experiment.

When heat-inactivated serum from immune donors was used as an opsonin, a small but significant reduction in virus concentration

Table 3. Effect of virus concentration on chemiluminescence production $^{1}$

\begin{tabular}{ccc}
\hline \multirow{2}{*}{$\begin{array}{c}\text { Virus concentration } \\
\text { per vial }\end{array}$} & \multicolumn{2}{c}{ Counts per min $^{2}$} \\
\cline { 2 - 3 } & Live virus & Killed virus \\
\hline$\left(\times 10^{7}\right)$ & $9,000 \pm 3,600$ & \\
0.04 & $15,000 \pm 4,500$ & \\
0.08 & $26,000 \pm 5,100$ & \\
0.10 & & $20 \pm 5$ \\
.20 & & $14 \pm 3$ \\
.40 & $50,000 \pm 6,000$ & \\
.50 & & $14 \pm 6$ \\
.60 & $72,000 \pm 9,500$ & \\
1.00 & $68,000 \pm 8,900$ & \\
1.72 & $90,000 \pm 10,000$ & \\
4.30 &
\end{tabular}

${ }^{1}$ Experimental conditions were as described in Table 2, except that no opsonin (antivaccinial antibody) was used.

${ }^{2}$ Mean \pm S.D. of peak counts per min of three experiments.

Table 4. Effect of opsonization on chemiluminescence production ${ }^{1}$

\begin{tabular}{cccc}
\hline $\begin{array}{c}\text { Experiment } \\
\text { No. }\end{array}$ & $\Delta$ Peak (\%) & $\Delta$ Slope (\%) & $\Delta$ Time $(\%)$ \\
\hline $1^{2}$ & 164 & 185 & 88 \\
2 & 295 & 294 & 0 \\
3 & 148 & 125 & 117 \\
4 & 383 & 788 & 48 \\
5 & 134 & 69 & 194 \\
mean & 224 & 292 & 89 \\
\hline
\end{tabular}

\footnotetext{
${ }^{1}$ Experimental conditions were as described in Table 2.

${ }^{2}$ Each experiment used heat inactivated $\left(56^{\circ} \mathrm{C}, 30 \mathrm{~min}\right)$ serum from a different donor. Results are expressed in \% change in peak counts per min ( $\Delta$ peak), the rate of CL production ( $\Delta$ slope) and time to peak CPM production ( $\Delta$ time) after addition of opsonin to live vaccinia virus and neutrophils (PMNs). The $100 \%$ level of CL was produced by live vaccinia and PMNs alone as defined in Table 2.
}

in the cell pellet (compared to virus alone and PMNs and virus) was seen. No reduction in the supernatant was noted. When FVIG was used as the opsonin, a marked reduction in virus titers was evident in both supernatant and cell fractions. Incubation of FVIG and virus for $15 \mathrm{~min}$ in the absence of PMNs also inactivated the virus, but as seen in the table, antibody appears to be responsible for only a portion of the inactivation. The incubation time does appear critical in that when virus and FVIG were incubated for $60 \mathrm{~min}$, the equivalent titers in supernatant and pellet fraction were $0.4 \pm 0.25 \times 10^{5}$ and $0.1 \pm 0.06 \times 10^{5}$, respectively; values in the same range as that seen with virus, PMNs and FVIG at 15 min of incubation.

Similar experiments were carried out with PMNs isolated from a patient with CGD (Table 6). The obvious difference from the control is the lack of comparable killing by CGD cells, even though apparent adherence of the virus to PMN was the same as normals. The virus to PMN ratio in these experiments was increased to 1.1 to 1 , however, in order to stress the CGD PMNs.

Summation of pellet and supernatant fractions showed an apparent loss of virus plaque-forming ability. This was particularly noticeable in the CGD experiments where the largest concentration of virus was used.

\section{DISCUSSION}

These data amplify the findings of previous studies of PMN:virus interaction in three areas. First, live virus particles activate $\mathrm{PMN} \mathrm{O}_{2}$ metabolism. Second, this activation occurs with and without opsonins. Third, PMNs appear to contribute to virus

Table 5. Inactivation of vaccinia virus by human neutrophils $(P M N s)^{1}$

\begin{tabular}{|c|c|c|c|c|}
\hline Experimental conditions & $\begin{array}{c}\text { Plaque- } \\
\text { forming } \\
\text { units virus } \\
\left(10^{5}\right)\end{array}$ & & $P$ value & \\
\hline Virus alone $^{2}$ & $4.3 \pm 0.5$ & & & \\
\hline Supernatant & $3.4 \pm 0.4$ & & & \\
\hline "Pellet" & $0.9 \pm 0.1$ & & & \\
\hline Virus and FVIG & $1.5 \pm 0.2$ & $<0.001^{3}$ & & \\
\hline Supernatant & $1.2 \pm 0.1$ & $<0.001$ & & \\
\hline "Pellet" & $0.3 \pm 0.03$ & $<0.001$ & & \\
\hline \multicolumn{5}{|l|}{ PMNs, virus, buffer } \\
\hline Supernatant & $1.2 \pm 0.6$ & $<0.001$ & & \\
\hline Pellet & $1.0 \pm 0.4$ & $>0.05$ & & \\
\hline \multicolumn{5}{|l|}{ PMNs, virus, $\mathrm{HI}^{4}$ serum } \\
\hline Supernatant & $2.4 \pm 0.9$ & $>0.05$ & $<0.05^{5}$ & \\
\hline Pellet & $0.5 \pm 0.2$ & $<0.01$ & $<0.05$ & \\
\hline \multicolumn{5}{|l|}{ PMNs, virus, FVIG ${ }^{6}$} \\
\hline Supernatant & $0.5 \pm 0.2$ & $<0.0001$ & $<0.05$ & $<0.001^{7}$ \\
\hline Pellet & $0.1 \pm 0.07$ & $<0.0001$ & $<0.05$ & $<0.005$ \\
\hline
\end{tabular}

${ }^{1}$ Mixtures of $6 \times 10^{6}$ PMNs and an average of $4 \times 10^{5}$ virus PFU with or without $0.1 \mathrm{ml}$ opsonin in a total volume of $1 \mathrm{ml}$ (MEM buffer) in 12 $\times 75 \mathrm{~mm}$ plastic tubes were incubated at $37^{\circ} \mathrm{C}$ for $15 \mathrm{~min}$ while rotating 7 times per min. After incubation the tubes were centrifuged $3 \mathrm{~min}$ at 200 $\times g$ at $4^{\circ} \mathrm{C}$. Samples from supernatants and cell pellets were assayed for virus; controls containing no PMNs were treated in a like manner. Virus particles were not centrifuged at this $g$ force, therefore virus quantity in "pellet" fractions of virus alone experiments represent dispersion of virus within the buffer.

${ }^{2}$ Values reported as mean \pm S.D. of four experiments (six replicates each); recorded as plaque-forming units virus/supernatant or pellet fraction.

${ }^{3}$ Compared to virus alone (paired $t$ test).

${ }^{4}$ Heat inactivated at $56^{\circ} \mathrm{C}, 30 \mathrm{~min}$.

${ }^{5}$ Compared to PMNs, virus and buffer (paired $t$ test).

${ }^{6}$ Filtered $(0.2 \mu)$ vaccinia immune globulin.

${ }^{7}$ Compared to virus and FVIG (paired $t$ test). 
Table 6. Inactivation of vaccinia virus by neutrophils (PMNs) from a patient with chronic granulomatous disease (CGD)

\begin{tabular}{lcc}
\hline & \multicolumn{2}{c}{ Plaque-forming units virus $\left(10^{5}\right)$} \\
\cline { 2 - 3 } Experimental conditions & CGD & Control \\
\hline Virus alone & $7.2^{2}$ & 7.0 \\
PMNs, buffer, virus & & \\
Supernatant & 1.4 & 0.8 \\
Pellet & 1.4 & 2.0 \\
PMN, virus, FVIG & & \\
Supernatant & 1.0 & 0.9 \\
Pellet & 1.5 & 0.4 \\
\hline
\end{tabular}

\footnotetext{
${ }^{1}$ Experimental conditions were as described under Table 5 with the exception of using $8 \times 10^{5}$ virus plaque-forming units/tube.

${ }^{2}$ Mean of duplicate experiments reported in plaque-forming units/ fraction.

${ }^{3}$ Filtered $(0.2 \mu)$ vaccinia immune globulin.
}

inactivation after short-term incubation, but only in the presence of specific antibody.

The mechanism by which unopsonized live virus triggers $\mathrm{O}_{2}$ metabolism remains to be determined. This phenomenon could result from membrane perturbation in a nonspecific fashion (15), especially because classical receptors associated with phagocytosis (C3b and Fc) were probably not activated $(26,20)$.

A second possibility is virus adherence to a specific receptor (29) during "infection" of the PMN. Influenza virus appears to adhere to glycoprotein residues (6), which if removed impair PMN $\mathrm{O}_{2}$ metabolism (31). These mechanisms appeared to be operative when influenza $\mathrm{A}$ was incubated with PMNs with or without opsonins (19).

Under experimental conditions similar to PMN bactericidal assays, inactivation of virus by PMNs occurred, but was only associated with specific antisera. The level of virus killing was greater with the high titered VIG than the random human serum although both sources enhanced killing in a dose dependent fashion. The study does not answer the question, "Is antibody the primary reason for virus inactivation?" PMNs may simply increase this effect. The results of the CL assay, however, suggest that antibody acts as an opsonin as well, in that the rate and peak of CL production are considerably enhanced. The experiments with CGD PMNs also suggest that neutralization by antibody is not the sole mechanism involved in virus inactivation in these experiments. The lack of neutralization with these abnormal cells suggests an active virucidal role for PMNs via oxygen dependent mechanisms.

The inability to account for all of the infectious virus in each experiment in the sum of the supernatant and pellet fractions highlights technical questions inherent in determining PMN effects upon virus viability. These differences were particularly apparent when cells and antibody were present in the mixtures. Virus particles tend to aggregate and disaggregate in the presence of antibody (7). Utilization of the plaque-forming unit as an endpoint in this study inadvertently may underestimate the number of viable virus particles. For example, each aggregate, whether it contains 2 or 20 viable virus particles, will be counted as one PFU. It is not known if similar aggregation occurs with live virus either adherent to or present within the cytoplasm of a PMN. Separation of antibody neutralization effect from that of PMN effect is likewise difficult; removal of the virus from the antibody by aliquot sampling and dilution did not appear to alter the antibody neutralization effect completely.

The biologic significance of these data and of PMNs in general in the host response to virus is not clear. In the immune host challenge with virus, particularly those agents which spread from cell to cell in the extracellular compartment (2), may well be met by phagocytosis of opsonized, neutralized particles by fixed phagocytic cells. Events in the nonimmune host, including adherence of virus to PMNs, "infection" of phagocytes and possible amplification of PMN by activation of nonspecific factors (complement), need to be evaluated before these questions can be answered.

A potential role for PMNs in clearing circulating immune complexes or initiating injury at sites of fixed complexes by release of enzymes or products of oxidative metabolism is more readily recognized $(12,24)$. The experiments demonstrating increase in $\mathrm{O}_{2}$ consumption by aggregated gamma globulin, and maximum stimulation of chemiluminescence by virus-antibody complexes support this role in immune-mediated injury. These data then support the concept that PMNs may play a primary role in the pathogenesis of and response to certain virus infections and that these phenomena deserve further study.

\section{REFERENCES AND NOTES}

1. Allen, R. C. and Loose, L. D.: Phagocytic activation of a luminol-dependent chemiluminescence in rabbit alveolar and peritoneal macrophages. Biochem. Biophys. Res. Comm., 69: 245 (1976).

2. Allison, A. C.: Interactions of antibodies, complement components, and various cell types in immunity against viruses and pyogenic bacteria. Transplant. Rev., 19: 3 (1974).

3. Babior, B. M.: Oxygen-dependent microbial killing by phagocytes. N. Engl. J. Med., 298: 659 (1978).

4. Belding, M. D., Klebanoff, S. J., and Ray, C. G.: Peroxidase-mediated virucidal systems. Science, 167: 195 (1970).

5. Brogan, M. D. and Sagone, A. L., Jr.: The metabolic response of human phagocytic cells to killed mumps particles. J. Reticulo. Endothel. Soc., 27: 13 (1980).

6. Choppin, P. W. and Scheid, A.: The role of viral glycoproteins in adsorption, penetration and pathogenecity of viruses. Rev. Infec. Dis., 2: 40 (1980).

7. Cooper, N. R.: Humoral immunity to viruses. In: H. Fraenbral-Conrat and R. R. Wagner, Ed. Comprehensive virology 15. (Plenum Press. New York, New York, 1979).

8. Downie, A. W. and Kempe, C. H.: Poxviruses. In: E. Lennette and N. Schmidt Ed. Diagnostic procedures for viral and rickettsial infections. p. 312 (American Public Health Association, New York, 1969).

9. Faden, H., Sutyla, P., and Ogra, P. L.: Effect of viruses on luminol-dependent chemiluminescence of human neutrophils. Infec. Immun., 24: 673 (1979).

10. Glasser, L., Huestis, D. W., and Jones, J. F.: Functional capabilities of steroidrecruited neutrophils harvested for clinical transfusion. N. Engl. J. Med., 297: 1033 (1977).

11. Henson, P. M. and Oades, F. G.: Stimulation of human neutrophils by soluble and insoluble immunoglobulin aggregates: Secretions of granule constituents and increased oxidation of glucose. J. Clin. Invest., 56: 1053 (1975).

12. Henson, P. M.: Interaction of cells with immune complexes: adherence release of constituents and tissue injury. J. Exp. Med., 134: 114S, (1971).

13. Joklik, W. K.: The purification of four strains of pox virus. Virology, 18: 9 (1962)

14. Klebanoff, S. J.: Antimicrobial mechanisms in neutrophilic polymorphonuclear leukocytes. Semin. Hematol., 12: 117 (1975).

15. Klebanoff, S. J. and Clark, R. A.: The neutrophil: Functional and clinical disorders. Chapter 6. (North-Holland Publishing Company, Amsterdam, Holland, 1978).

16. Larson, H. E. and Blades, R.: Impairment of human polymorphonuclear leukocyte functions by influenza virus. Lancet, $I: 283$ (1976).

17. Leddy, J. P., Simons, R. L., and Douglas, R. G.: Effect of selective complement deficiency on the rate of neutralization of enveloped viruses by human sera. $J$. Immunol., 118: 28 (1977).

18. MacFarlane, P. S., Speirs, A. L., and Somerville, R. G.: Fatal granulomatous disease in childhood and benign lymphocytic infiltration of the skin (congenital dysphagocytosis). Lancet, $1: 408$ (1967).

19. Mills, E. L., Quie, P. G., and Verhoef, J.: The effect of specific antisera on virusinduced neutrophil chemiluminescence. Pediatr. Res., 15: 600 (1981).

20. Newman, S. L. and Johnston, Jr., R. B.: Role of binding through C3b and IgG in polymorphonuclear neutrophil function: Studies with trypsin-generated C $3 \mathrm{~b}$. J. Immunol., 123: 1839 (1979).

21. Oleske, J. M., Ashman, R. B., Kohl, S., Shore, S. L., Starr, S. E., Wood, P., and Nahmias, A. J.: Human polymorphonuclear leukocytes as mediators of antibody-dependent cellular cytotoxicity to herpes simplex virus-infected cells. Clin. Exp. Immunol., 27: 446 (1977).

22. Quie, P.: Pathology of bactericidal power of neutrophils. Semin. Hemat., 12: 143 (1975).

23. Rouse, B. T., Babiuk, L. A., and Henson, P. M.: Neutrophils in antiviral immunity: inhibition of virus replication by a mediator produced by bovine neutrophils. J. Infec. Dis., 141: 223 (1980).

24. Sacks, T., Moldow, C. F., Craddock, P. R., Bowers, T. K., and Jacob, H. S.: Oxygen radicals mediate endothelial cell damage by complement-stimulated granulocytes. J. Clin. Invest., 61: 1161 (1978).

25. Sawyer, W. D.: Interaction of influenza virus with leukocytes and its effect on phagocytosis. J. Infec. Dis., 119: 541 (1969).

26. Scribner, D. J. and Fahrney, D.: Neutrophil receptors for IgG and complement: their roles in the attachment and ingestion phages of phagocytosis. J. Immunol, 116: 892 (1976). 
27. Sisson, J. G. P. and Oldstone, M. B. A.: Antibody-mediated destruction of virusinfected cells. Adv. Immunol., 29: 209 (1980).

28. Sosman, J. and Busse, W.: Altered luminal granulocyte chemiluminescence during an in vitro incubation with an influenza vaccine. J. Allergy Clin. Immunol., 65: 224 (1980).

29. Smith, H.: Host and tissue specificities in virus infections of animals. In: G. Poste and G. L. Nicolson Ed. Virus infection and the cell surface. p. 4-11 (NorthHolland, Amsterdam, Holland, 1977).

30. Stankova, L., Drach, G. W., Hicks, T., Zukoski, C. F., and Chvapil, M.: Regulation of some functions of granulocytes by zinc of the prostatic fluid and prostate issue. J. Lab. Clin. Med., 88: 640 (1976).

31. Tsan, M. F. and McIntyre, P.: The requirement for membrane sialic acid in the stimulation of superoxide production during phagocytosis by human polymorphonuclear leukocytes. J. Exp. Med., 143: 1308 (1976).

32. Wardley. R. C., Rouse, B. T., and Babiuk, L. A.: Antibody dependent cytotoxicity mediated by neutrophils: A possible mechanism of antiviral defense. J. Reticulo. Endothel. Soc., 19: 323 (1976).

33. Wilkinson, P. C.: Leukocyte locomotion and chemotaxis: effects of bacteria and viruses. Rev. Infec. Dis., 2: 293 (1980).

34. This work presented in part at the Western Society for Pediatric Research, Carmel, Calif., February 1980.

35. The author thanks Zita Ingham and Marlene Stahl for excellent technical assistance.

36. The author is the recipient of National Institutes of Health New Investigator Award, AI 18210.

37. Please address reprint requests to Dr. James F. Jones, Department of Pediatrics, Arizona Health Sciences Center, 1501 N. Campbell Avenue, Tucson, Arizona 85724 (USA).

38. Received for publication June $24,1981$.

39. Accepted for publication November 12, 1981.

\begin{abstract}
ANNOUNCEMENT
The publication, "Protecting Human Subjects," was prepared for the President of the United States and the Congress by the President's Commission for the Study of Ethical Problems in Medicine and Biomedical and Behavioral Research. This publication is now available for $\$ 6.50$, Stock No. 040-000-00452-1. All orders should be accompanied by a check or money order made payable to the Superintendent of Documents. International orders must be accompanied by payment drawn on a United States or Canadian bank plus an additional $25 \%$ of total order for international handling.
\end{abstract}

Address inquiries to:

Superintendent of Documents

U.S. Government Printing Office

Washington, D.C. 20402

\title{
ANNOUNCEMENT
}

The three-day course, first in Europe, will include plenary sessions, lectures and concomitant workshops covering a schedule of 50 hours. On the 4th day, October 17, there will be a round table open also to different staffs and families. This Course is designed primarily for pediatricians, geneticists, cytogeneticists, obstetricians, biologists and other scientists involved in Birth Defects. Active participation of the registrants will be encouraged in the workshops and by question-and-answers panels after lectures.

There will be ample opportunity for informal discussions. Poster sessions will be available.

The tuition fee, $\$ 130$, includes also 3 lunches and one dinner-dance in the Chianti countryside. Students and research fellows, $\$ 70$.

The Guest Faculty will consist of distinguished speakers from different countries: Cohen M. M. (Canada), Der Kaloustian V. M. (Lebanon), Emery A. (Scotland), Galjaard H: (Netherlands), German J. L. III (U.S.A.), Gorlin R. J. (U.S.A.), Hall J. G. (Canada), Harper P. S. (U.K.), Klein D. (Switzerland), Laurence K. M. (U.K.), Lindsten J. (Sweden), Mikkelsen M. (Denmark), Milunsky A. (U.S.A.), Motulsky A. G. (U.S.A.), Opitz J. M. (U.S.A.), Polani P. (U.K.), Rehder H. (Germany), Réthoré O. (Francia), Rimoin D. L. (U.S.A.), Sperling K. (Germany), Spranger J. (Germany), Weatherall J. A. C. (U.K.), Williamson R. (U.K.), Wolf U. (Germany).

Chairman:

M. FRACCARO, University of Pavia

Scientific Secretary:

Co chairmen:

M. L. GIOVANNUCGI UZIELLI

A. FOIS, University of Siena

Human Genetics Service

M. GIUSTI, Children Hospital Florence

Institute of Pediatrics

University of Florence

For further information contact:

Organizing Secretariat

Identification Genetic Syndromes

Ospedale Pediatrico A. Meyer

Via L. Giordano, 13

50132 Florence-Italy

Phone 055/57.59.53 